Published online: 02 December 2019

\title{
Author Correction: Ground reference data for sugarcane biomass estimation in São Paulo state, Brazil
}

Ramses A. Molijn, Lorenzo lannini, Jansle Vieira Rocha \& Ramon F. Hanssen

Correction to: Scientific Data https://doi.org/10.1038/sdata.2018.150, published online 07 August 2018

Following publication, it was noticed that the horizontal brackets labelling the two groups of precisions present in Equation 7 are incorrectly rendered in the PDF version of this Data Descriptor. The correct Equation 7 is as follows:

$$
\begin{aligned}
\sigma_{T C H}= & {\left[(\underbrace{\sqrt{\vartheta_{T S H}+\chi_{T S H}} \cdot|T S H|}_{1})^{2}+\right.} \\
& \left.+(\underbrace{\sqrt{\vartheta_{T L H}+\chi_{T L H}} \cdot|T L H|}_{2})^{2}\right]^{1 / 2}
\end{aligned}
$$

In addition, in the Biomass subsection of the Methods section in both the HTML and PDF versions, the term "ESUs" is incorrectly rendered as "ESUâ $€^{\mathrm{TM}} \mathrm{s}$ " and the term ESUBs is incorrectly rendered as "ESUBâ ${ }^{\mathrm{TM}} \mathrm{s}$ "

Finally, throughout the manuscript, references to sections and subsections include the prefixes "sec:" and "subsec:", respectively. These prefixes and any hyphen between the reference words that follow the prefixes can be ignored.

(c) (i) Open Access This article is licensed under a Creative Commons Attribution 4.0 International License, which permits use, sharing, adaptation, distribution and reproduction in any medium or format, as long as you give appropriate credit to the original author(s) and the source, provide a link to the Creative Commons license, and indicate if changes were made. The images or other third party material in this article are included in the article's Creative Commons license, unless indicated otherwise in a credit line to the material. If material is not included in the article's Creative Commons license and your intended use is not permitted by statutory regulation or exceeds the permitted use, you will need to obtain permission directly from the copyright holder. To view a copy of this license, visit http://creativecommons.org/licenses/by/4.0/.

(c) The Author(s) 2019 